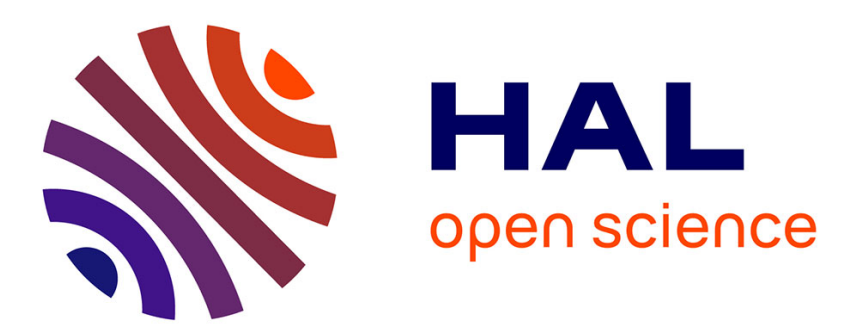

\title{
Interaction techniques for older adults using touchscreen devices: a literature review from 2000 to 2013
}

\author{
Lilian Genaro Motti, Nadine Vigouroux, Philippe Gorce
}

\section{To cite this version:}

Lilian Genaro Motti, Nadine Vigouroux, Philippe Gorce. Interaction techniques for older adults using touchscreen devices: a literature review from 2000 to 2013. Journal d'Interaction Personne-Système, 2017, Volume 3, Issue 2, Special Issue: Best of IHM'2013 (2), pp.1-26. 10.46298/jips.3180 . hal01480330

\section{HAL Id: hal-01480330 \\ https://hal.science/hal-01480330}

Submitted on 1 Mar 2017

HAL is a multi-disciplinary open access archive for the deposit and dissemination of scientific research documents, whether they are published or not. The documents may come from teaching and research institutions in France or abroad, or from public or private research centers.
L'archive ouverte pluridisciplinaire HAL, est destinée au dépôt et à la diffusion de documents scientifiques de niveau recherche, publiés ou non, émanant des établissements d'enseignement et de recherche français ou étrangers, des laboratoires publics ou privés. 


\title{
Interaction techniques for older adults using touchscreen devices: a literature review from 2000 to 2013
}

\author{
LILIAN GENARO MOTTI \\ IRIT - UMR 5505, Université de Toulouse 3 Paul Sabatier \\ NADINE VIGOUROUX \\ IRIT - UMR 5505, Université de Toulouse 3 Paul Sabatier \\ PHILIPPE GORCE \\ HandiBio - EA 43 22, Université du Sud Toulon Var
}

\begin{abstract}
Résumé : Des progrès considérables des technologies mobiles ont été constatés sur les quinze dernières années, notamment avec le développement des écrans tactiles. Depuis que le vieillissement est un phénomène démographique mondial, plusieurs études ont été menées pour étudier et améliorer l'interaction des personnes âgées avec ces nouvelles technologies. Ces études sont importantes car les dispositifs mobiles, souvent équipés d'un écran tactile,peuvent aider à améliorer la qualité de vie des personnes âgées (soins de santé, maintien du lien social, jeux sérieux). Comprendre l'interaction de ce groupe d'utilisateurs avec des écrans tactiles peut ainsi faciliter l'adoption des technologies interactives et leur future utilisation. Cette revue de la littérature analyse trente-six études qui ont évalué des techniques d'interaction pour des sujets âgés utilisant des dispositifs avec écran tactile. Cette revue vise 1) à analyser la situation de ces trente-six études (population, équipements, tâches et techniques d'interaction) et 2) à identifier les situations d'utilisation des écrans tactiles et des techniques d'interaction qui doivent encore être étudiées. Les résultatssont l'analyse descriptive des populations incluses, des dispositifs choisis, des tâches effectuées et des techniques d'interaction, ainsi qu'unesynthèse des paramètres pertinents à prendre en compte pour des études sur les techniques d'interaction tactile. Sur chaque point, nous présentons une discussion sur les résultats, les recommandations des auteurs et des repères pour des travaux futurs.
\end{abstract}

Mots clés :Ecran tactile, techniques d'interaction, personnes âgées.

Abstract: Some remarkable advances in mobile technologies have been made on the past fifteen years, especially the adoption of direct input on the screen. Since aging is now a worldwide demographic phenomenon, several studies have been carried on to investigate and improve the interaction between olderaged adults and these new technologies. These studies are important because mobile devices are often equipped with touchscreen and they can help to improve quality of life for older adults (health care, social life, serious games). Understanding interaction of this group of userswith touchscreen can facilitate the adoption of interactive technologies and their future use by older populations. This literature review analyses thirty six studies that evaluated interaction techniques for older users using touchscreen devices. This review intends to 1) analyze the situation of thirty six studies (population, apparatus, tasks and interaction techniques) and 2) identify situations of use of touchscreen devices and interaction techniques that need to be further studied. As results, a descriptive analysis of the populations included, the chosen apparatus, executed tasks and interaction techniques are presented, so as a summary of relevant parameters to consider for studies of tactile interaction techniques. On each topic, we discuss about the results, the authors' recommendations and we provide cues for future work.

Key words: Touchscreens, tactile interaction, older adults.

Adresse des auteurs : Lilian Genaro Motti (genaro@irit.fr), Nadine Vigouroux (vigourou@ irit.fr), IRIT UMR 5505, Université de Toulouse 3 Paul Sabatier, 118 Route de Narbonne, 31062, Toulouse, France.Philippe Gorce(gorce@univ-tln.fr), HandiBio EA 43 22, Université du Sud Toulon Var, Avenue de l'université, 83957, Toulon, France.

Les articles de JIPS sont publiés sous licence Creative Commons Paternité 2.0 Générique. 


\section{INTRODUCTION}

Some remarkable advances in mobile technologies have been made during the past fifteen years, especially the adoption of direct input on the screen. Since aging is now a worldwide demographic phenomenon, several studies have been done to investigate and improve tactile interaction for older adults.

Touchscreen interaction has been recommended for older adults for several reasons. First, direct interaction requires less cognitive, spatial or attentional demand [Caprani et al. 2012; Wood et al. 2005]. It has been shown that touchscreen interaction reduces movement times and number of errors, reducing the age-related differences in performances when compared to traditional computer input devices as mouse [Findlater et al. 2013; Schneider et al. 2008] or physical keypads [Chung et al. 2010]. Touchscreen interaction is also easy to learn for users without experience with computers and it reduces the resistance of older adults towards new technologies [Umemuro 2004; Gonçalves and Ueyama 2012].

These studies are important because mobile devices can help to improve quality of life for older adults (health care, social life, serious games). Touchscreen equipment is suitable to be used everywhere because it does not need intermediary devices.Most of handheld devices are equipped with touchscreen nowadays and so are public kiosks in train stations, airports or banking systems are also equipped with touchscreen devices [Chung et al. 2010]. Therefore, improving the way older people use touchscreen devices is also important to prevent digital exclusion.

Studies of touchscreen interaction of older adults intend to provide guidelines and recommendations in order to facilitate the design of applications destined to the elder populations. For example, e-health applications provide medical assistance or home care [Nischelwitzer and Pintoffl 2007; Piper et al. 2010; Holzinger 2003; Iglesias et al. 2009] or social network applications help older users to keep in touch with their families and friends, sharing information and preventing from isolation. Ludic activities and serious games can be used get information, obtain therapeutic effects and also support cognitive stimulation [Ijsselsteijn et al. 2007]. Besides, they could help beginners to discover new technologies and learn tactile interaction[Motti et al. 2014].

However, the incidence of sensorial, motor or cognitive impairment on older populations is important due to the age related changes during normal or pathological ageing. For this reason, some authors have studied the difficulties of computer traditional input by older people with low motor skills [Smith et al. 1999] or cognitive impairment [Vigouroux et al. 2009]. The use of touchscreen devices has been considered to older users visually impaired [Leonard et al. 2005]. Take into account the different characteristics of users and the individual age-related changes on interaction studies is important so designers and developers can provide support and propose new interactions techniques adapted to the users' special needs.

Several studies evaluated interaction techniques for older users using touchscreen. There is a great variability among the included participants, the chosen devices and the parameters of study. This review shows that they do not embrace all the situations of use neither the characteristics of older populations. The main objective of this review is to identify non-studied situations and interaction techniques and propose new studies. The next section presents the related work and places the contributions of the present review. Section 3 describes the methodology of the selection and analysis of thirty six studies. Section 4 shows the results of this comparative analysis. Section 5 presents a discussion. Finally, a conclusion is presented on section 6. 


\section{RELATED WORK}

The number of works concerning human-computer interaction of older adults reveals the importance researchers of different fields of knowledge have been given to this subject the past fifteen years. However, new interaction techniques and devices are being developed and continuously launched into the market, thereby more studies have to be done to improve existing techniques and propose new ones.

The existing reviews of the literature on tactile interaction for older adults do not embrace all the parameters affecting human-computer interaction.

There are reviews summarizing design recommendations for graphical user interfaces of applications destined to be used by older adults. These design recommendations concern buttons sizes, font sizes and layout advices based on interaction studies as well as assessment ofusers' subjective appreciation and satisfaction [Gudur et al. 2013; Rau and Hsu 2005].Nevertheless, the variability of devices and situations of use as well as different input modalities and interaction techniques are not reported.

Three other reviews on tactile interaction of older adults have been found. Two of them focus on one specific situation of use. They do not discuss the different contexts of use of mobile devices. Al-Razgan et al (2012) presented a survey of the literature about guidelines for mobile phones destined to older users. In their work, they emphasize graphical user interfaces and layout recommendations, simplifying the interaction techniques and the differences between users [Al-Razgan et al. 2012]. Zhou et al (2012) presented a review about handheld computers for older adults. They discuss the acceptability and the usability of handheld devices by this population but they do not discuss the advantages or problems of interaction techniques on touchscreen. Loureiro \& Rodrigues (2014) presented a review on design guidelines for touchscreen interfaces and their work stablishes a set of design recommendations to help designers and developers to create applications for older adults. The work of Loureiro \& Rodrigues (2014)is based on theclassification of Kurniawam \& Zaphiris (2005), concerning web accessibility guidelines for older users[Kurniawan and Zaphiris 2005]. However, new ways of interacting with web content and applications on touchscreen devices canhardlybe fit in the classification for web accessibility guidelines. As pointed out by Loureiro \& Rodrigues (2014), the suitability of gestures of interaction for older adults using touchscreenshould be further studied [Loureiro and Rodrigues 2014].

Other literature reviews about human-computer interaction of older users discuss how the direct input on the display can enhance older user's performances, highlighting the advantages and disadvantages of the use of touchscreen technologies by older adults [Caprani et al. 2012; Taveira and Choi 2009].

The main contribution of the present review is to analyze the different parameters and situations of the studies on tactile interaction we selected. By doing so, we will be able to identify the contexts of use of touchscreen devices that should be further studied.

Besides, older users are a heterogeneous group. In addition to the individual agerelated changes, user's background and previous experiences affects the way they perceive and interact with technologies. It is not easy to take into account the variability of this population [Wöckl et al. 2012; Sears and Hanson 2011] and it is also difficult to follow the evolution of their characteristics [Hanson 2009]. To overcome this problem, some of the selected studies applied user-centered design methods and participatory evaluation of applications in spite of the difficultiesof including older adults as participants on design evaluation and experimental studies[Dickinson et al. 2007]. 


\section{METHODOLOGY}

The studies we selected include older adults as participants for design evaluation sessions or experiments that evaluateexisting interaction techniques or propose new onesfor interacting with touchscreen flat displays. Authors represent research groups that are placed in most of the countries where older adults represent an important part of the population (Europe, North-America, and Asia).

The study of the interaction of older adults andinteractive technologies is an important topic on different research fields and the object of multidisciplinary studies. Assistive technologies, Ergonomics and Computer science are the main research fields interested in evaluating interaction techniques for older users. This is a non-exhaustive review. Thirty six studies have been selected from peer-reviewed conferences and journals on Human-computer interaction (ACM CHI, Int. Journal of HCI, BCS-HCI, INTERACT, Gestures Workshop, Universal Access on HCI, ACM Transactions on Accessible Computing, Universal Accesson the Information Society, Journal of AppliedGerontology, Ergonomics, Human factors and Ergonomics Society, USAB, Engineering of Interaction on Computer Science):

- 14 studies from human-computer interaction field, from 2006 to 2013

- 13 studies from the assistive technologies field, from 2004 to 2012

- 6 from psycho-motor and ergonomics research field, from 2000 to 2010

- 2 studies from healthcare research field, on 2010 and 2013

- 1 from computers science published in 2010.

Some of these studies outcomes from the same experiment, but present extended results and contributions.

The following section presents the results of our comparative analysis. First, we describe the characteristics of the older participants included on these studies. Then, we describe the apparatus, the tasks and the interaction techniques evaluated. In order to facilitate the reading, interaction techniques have been divided in two categories: input, including input modalities and gestures of interaction, and output, mainly about providing multimodal feedback. Each topic contains a descriptive analysis with a summary of relevant parameters and a discussion about the results, the authors' recommendations and cues for future work.

\section{RESULTS}

\subsection{Population}

\subsubsection{Description}

The number of older adults included on the analyzed studies varies between 3 and 85 subjects. Subjects were aged 50 to 94 years old.

Fourteen studies only had older participants [Leonard et al. 2005; Leitao and Silva 2013; Wood et al. 2005; Hwangbo et al. 2013; Tsai and Lee 2009; Harada et al. 2013; Lee et al. 2009; Jin et al. 2007; Kobayashi et al. 2011; Mertens and Jochems 2010; Umemuro 2004; Wacharamanotham 2011; Gonçalves and Ueyama 2012; Nicolau and Jorge 2012]. Nineteen compared the performances between different groups of ages [Stößel et al. 2010; Schneider et al. 2008; Piper et al. 2010; Chung et al. 2010; Findlater et al. 2013; Apted et al. 2006; Hollinworth and Hwang 2011; Hourcade and Berkel 2006; Iglesias et al. 2009; Lepicard and Vigouroux 2010b; Lepicard and Vigouroux 2012; Lepicard and Vigouroux 2010a; Moffatt and McGrenere 2007; Umemuro 2004; Vetter et al. 2011; Wright et al. 2000; Nischelwitzer and Pintoffl 2007; Jastrzembski et 
al. 2005; Charness et al. 2004; Rogers et al. 2005]. The others compared interaction performances between different age groups.

Age was a significant predictor of performance for all these studies, but authors who assessed manual dexterity state that it is also a strong factor [Nicolau and Jorge 2012]. The incidence of sensory, cognitive or motor impairments increases with ageing. Even though, only able-bodied older adults participated of 18 studies [Findlater et al. 2013; Lepicard and Vigouroux 2012; Lepicard and Vigouroux 2010a; Lepicard and Vigouroux 2010b; Hwangbo et al. 2013; Harada et al. 2013; Hourcade and Berkel 2006; Kobayashi et al. 2011; Tsai and Lee 2009; Leitao and Silva 2013; Umemuro 2004; Vetter et al. 2011; Wood et al. 2005; Wright et al. 2000; Stößel et al. 2010; Jastrzembski et al. 2005; Charness et al. 2004; Rogers et al. 2005].

Eighteen authors evaluated the skills of the users before the experiment by means of self-report or evaluation methods. Sometimes, these measures were used to determine inclusion or exclusion criteria. Table 1synthetizes pre-experiment measurement of skills or impairments. Six studies assessed visual acuity and one included visually impaired users on the study (age-related macular degeneration - AMD). Eight assessed auditory skills, four of them provided audio feedback and two of them included users wearing hearing aids. Ten studies assessed cognitive skills but one included users with low levels of attention and concentration. Fourteen studies assessed motor skills or manual dexterity, two of them included users with tremor and the other three included users with relatively low manual dexterity.

Visual or hearing acuity were assessed through tests or participants were just questioned about it.

Cognitive skills were evaluated with computer assisted tests or standardized measures [Tsai and Lee 2009; Wood et al. 2005; Rogers et al. 2005; Jastrzembski et al. 2005; Charness et al. 2004; Wright et al. 2000]. Cognitive impairment has shown effects on interaction with technologies and this effects have been studied to older users [Vella et al. 2011]. But only one study included older users with low cognitive skills [Tsai and Lee 2009].

Motor skills or impairment, as manual dexterity, were measured with different methods as Purdue Pegboard test, Grooved Pegboard test or paper folding test for manual dexterity [Jin et al. 2007; Moffatt and McGrenere 2007; Wood et al. 2005; Leonardi et al. 2010], combined with Digit Symbol Substitution for speed [Moffatt and McGrenere 2007], and others. Archimedes spiral drawing [Nicolau and Jorge 2012; Wacharamanotham 2011], accelerometers [Wacharamanotham 2011] or 9 holes steadiness were used to measure tremor [Wacharamanotham 2011; Moffatt and McGrenere 2007]. Operations on calculators were used to measure keyboard dexterity [Wright et al. 2000].

Some studies compared the performances between groups of subjects with different manual dexterity [Jin et al. 2007],motor [Wacharamanotham 2011] or cognitive skills [Tsai and Lee 2009]. 
Table 1. Pre-experiment measurement of skills of the subjects and the inclusion criteria of subjectswith disabilities on the studies.

\begin{tabular}{|c|c|c|c|}
\hline $\begin{array}{l}\text { Skills or } \\
\text { impairments }\end{array}$ & Measurement & $\begin{array}{l}\text { Self-report } \\
\text { information }\end{array}$ & $\begin{array}{l}\text { Subjects with } \\
\text { disabilities included on } \\
\text { the study }\end{array}$ \\
\hline Visual & $\begin{array}{l}4 \text { studies } \\
\text { [Leonard et al. 2005; } \\
\text { Charness et al. 2004; } \\
\text { Jastrzembski et al. 2005; } \\
\text { Rogers et al. 2005] }\end{array}$ & $\begin{array}{l}2 \text { studies } \\
\text { [Stößel et al. 2010; } \\
\text { Lee et al. 2009] }\end{array}$ & $\begin{array}{l}\text { AMD } \\
\text { [Leonard et al. 2005] }\end{array}$ \\
\hline Auditory & $\begin{array}{l}4 \text { studies } \\
\text { [Hwangbo et al. 2013; } \\
\text { Charness et al. 2004; } \\
\text { Jastrzembski et al. 2005; } \\
\text { Rogers et al. 2005] }\end{array}$ & $\begin{array}{l}4 \text { studies } \\
\text { [Lee et al. 2009; } \\
\text { Wood et al. 2005; } \\
\text { Kobayashi et al. } \\
\text { 2011; Iglesias et al. } \\
\text { 2009] }\end{array}$ & $\begin{array}{l}\text { Hearing aid } \\
\text { [Wood et al. 2005; } \\
\text { Kobayashi et al. 2011] }\end{array}$ \\
\hline Cognitive & $\begin{array}{l}6 \text { studies } \\
\text { [Wood et al. 2005; Tsai } \\
\text { and Lee 2009; Leonard et } \\
\text { al. 2005; Charness et al. } \\
\text { 2004; Jastrzembski et al. } \\
\text { 2005; Rogers et al. 2005] }\end{array}$ & $\begin{array}{l}4 \text { studies } \\
\text { [Leonard et al. } \\
\text { 2005; Lepicard and } \\
\text { Vigouroux 2010a; } \\
\text { Lepicard } \\
\text { Vigouroux } 2012 ; \\
\text { Iglesias et al. 2009] }\end{array}$ & $\begin{array}{l}\text { Low attention and } \\
\text { concentration levels } \\
\text { [Tsai and Lee 2009] } \\
\text { Emotivity } \\
\text { [Iglesias et al. 2009] }\end{array}$ \\
\hline Motor & $\begin{array}{l}9 \text { studies } \\
\text { [Leonard et al. 2005; Tsai } \\
\text { and Lee 2009; Jin et al. } \\
2007 \text { Mertens and } \\
\text { Jochems 2010; Nicolau } \\
\text { and Jorge } 2012 ; \\
\text { Wacharamanotham 2011; } \\
\text { Schneider et al. 2008; } \\
\text { Wright et al. 2000; } \\
\text { Charness et al. 2004; } \\
\text { Jastrzembski et al. 2005; } \\
\text { Rogers et al. 2005] }\end{array}$ & $\begin{array}{lr}5 \text { studies } & \\
\text { [Stößel et al. } 2010 ; \\
\text { Piper et al. } & 2010 ; \\
\text { Lepicard } & \text { and } \\
\text { Vigouroux } & 2012 ; \\
\text { Lepicard } & \text { and } \\
\text { Vigouroux } & 2010 \mathrm{a} ; \\
\text { Lepicard } & \text { and } \\
\text { Vigouroux } & 2010 \mathrm{~b} \text { ] }\end{array}$ & $\begin{array}{l}\text { Arthritis } \\
\text { [Piper et al. 2010] } \\
\text { Tremor } \\
\text { [Piper et al. 2010; } \\
\text { Mertens and Jochems } \\
\text { 2010; Nicolau and Jorge } \\
\text { 2012; Wacharamanotham } \\
\text { 2011] } \\
\text { High and low accuracy } \\
\text { [Tsai and Lee 2009; Jin } \\
\text { et al. 2007] }\end{array}$ \\
\hline
\end{tabular}

The different performances of participants during interaction with technologies can also be related to theirbackground. Sixteen authors questioned subjects about their personal history, including attitudes towards technologies, health conditions, educational levels and reading skills. 
Table 2summarizes the characteristics of the background of participants and the use of these criteria for performance evaluation. 
Table 2.Background of the subjects and the use of theseas criteria for performance evaluation.

\begin{tabular}{|l|l|l|}
\hline Background information & $\begin{array}{l}\text { Subjects were questioned about } \\
\text { it }\end{array}$ & $\begin{array}{l}\text { Criteria for performance } \\
\text { evaluation }\end{array}$ \\
\hline $\begin{array}{l}\text { Attitudes towards } \\
\text { technologies }\end{array}$ & $\begin{array}{l}\text { 4 studies studies } \\
\text { [Findlater et al. 2013; Umemuro } \\
\text { 2004; Gonçalves et al. 2011; } \\
\text { Mertens and Jochems 2010] }\end{array}$ & $\begin{array}{l}\text { [Findlater et al. 2013; Mertens } \\
\text { and Jochems 2010] }\end{array}$ \\
\hline Health conditions & $\begin{array}{l}\text { 4 studies } \\
\text { [Iglesias et al. 2009; Piper and }\end{array}$ & - \\
& $\begin{array}{l}\text { Hollan 2013; Hollinworth and } \\
\text { Hwang 2011; Nischelwitzer and } \\
\text { Pintoffl 2007] }\end{array}$ & \\
\hline Education & $\begin{array}{l}\text { 2 studies } \\
\text { [Tsai and Lee 2009; Gonçalves } \\
\text { and Ueyama 2012] }\end{array}$ & $\begin{array}{l}\text { [Gonçalves and Ueyama } \\
\text { 2012] }\end{array}$ \\
\hline Reading skills & $\begin{array}{l}\text { 2 studies } \\
\text { [Gonçalves and Ueyama 2012; } \\
\text { Wright et al. 2000] }\end{array}$ & \\
\hline
\end{tabular}

Previous experience with information computers, internet, mobile phones or touchscreen was considered as a predictor for the performances of older users for several studies. Table 3 shows the studies where subjects were questioned about their previous experience with information and communication technologies (ICTs) and those who used it as criteria of inclusion or exclusion of participants. This information was accessed by self-report, interview or standardized questionnaires [Schneider et al. 2008].

Table 3. Previous experience with ICTs and inclusion criteria for subjects.

\begin{tabular}{|c|c|c|}
\hline $\begin{array}{l}\text { Previous experience } \\
\text { with ICTs }\end{array}$ & $\begin{array}{l}\text { Pre-experiment verification/ } \\
\text { Subjects questioned about it }\end{array}$ & $\begin{array}{l}\text { Subjects with previous } \\
\text { experience with ICT } \\
\text { included on the study }\end{array}$ \\
\hline Computers & $\begin{array}{l}5 \text { studies } \\
\text { [Wood et al. 2005; Stößel et al. } \\
\text { 2010; Leonard et al. 2005; } \\
\text { Schneider et al. 2008; Findlater et } \\
\text { al. 2013] }\end{array}$ & $\begin{array}{l}4 \text { studies } \\
\text { [Wood et al. 2005; Stößel et } \\
\text { al. 2010; Leonard et al. 2005; } \\
\text { Schneider et al. 2008] }\end{array}$ \\
\hline Mobile phones & $\begin{array}{l}5 \text { studies } \\
\text { [Leonard et al. 2005; Lee et al. } \\
\text { 2009; Kobayashi et al. 2011; } \\
\text { Umemuro 2004; Harada et al. } \\
\text { 2013] }\end{array}$ & $\begin{array}{l}1 \text { study } \\
\text { [Lee et al. 2009] }\end{array}$ \\
\hline Touchscreen & $\begin{array}{l}1 \text { study } \\
\text { [Chung et al. 2010] }\end{array}$ & $\begin{array}{l}1 \text { study } \\
\text { [Findlater et al. 2013] }\end{array}$ \\
\hline
\end{tabular}

\subsubsection{Discussion}

Older adults are a very heterogeneous population. Motor, sensorial and cognitive skills qualify individual characteristics. Besides, special needs or handicap change during lifetime, they can be temporary or degenerative.In addition to this, older users have different background, health conditions, education, and previous experience with technologies, as well as attitudes towards computers.

The analysis of the included population showed that some of reviewed studies included older adults with special needs, different backgrounds, novices or more 
experienced users. The effects of the users' profile on the performance have not yet been studied, but there are evidences that they should be considered during interaction research.

Future work should provide information and recommendations for older adults with special needs and different backgrounds. Another important aspect to consider is the experience of use. Few studies included users with previous experience of use of computers, mobile phones and touchscreen devices. Following the popularization of touchscreen devices, more and more users will have previous experience with tactile interaction. More studies need to be done to investigate the ICTs proficiency of long term users and its effects on their performances when interacting with technologies.

When designing or developing an application to older users it is not possible to preview skills, disabilities or background of final users. Ideally, systems need to consider their diversity and try to be flexible and adaptive. Allowing customization could also help to respond to the user's different needs.

\subsection{Apparatus}

\subsubsection{Description}

The touchscreen devices chosen for these studies had different screen sizes, from 3.5 to 42 inches. Only two studies compared interaction between two screen sizes (smartphone and tablet) [Harada et al. 2013; Kobayashi et al. 2011].

Screen resolution and touchscreen technologies have been improved over the past 10 years, allowing higher image quality and touch sensitivity. Screen resolution affects pixel sizes on the display and consequently the higher touchscreen resolution affects precision for detecting touch contact.

Resistive touchscreens need constant pressure. Some authors reported that older users had difficulties to maintain pressure during long gestures of interaction [Wood et al. 2005]. Capacitive touchscreens are highly sensitive but authors report unregistered and accidental touches [Harada et al. 2013]. The resolution and the touchscreen technologies are not always specified by authors.

Screen orientation and position generally modify the layout and the interaction. Landscape mode allows bigger key sizes on small portable devices, i.e. during text entry tasks [Nicolau and Jorge 2012], but portrait mode can be suitable for right and left handed users. Horizontal positions are common for fixed devices or tabletops, but $30^{\circ}$ inclination offers a better visual comfort for reading tasks [Piper et al. 2010].

Screen sizes affect the layout of the content but also the way users interact with the devices. Portable devices such as smartphones have small screen sizes, they are lightweighted and commonly used handheld [Nicolau and Jorge 2012]. Some studies simulate small screen sizes layout on bigger touchscreen monitors, that are generally fixed on vertical position [Jin et al. 2007; Chung et al. 2010; Lee et al. 2009]. Bigger portable devices as tablets were used to study larger gestures of interaction [Stößel et al. 2010; Harada et al. 2013]. Surfaces and tabletops were fixed horizontally and employed for collaborative or multi-users tasks [Apted et al. 2006; Piper et al. 2010]. 
Table 4summarizes the parameters and configuration of the apparatus of these studies. 
Table 4. Apparatus configuration on the studiesreviewed.

\begin{tabular}{|l|l|}
\hline Device characteristics & Configuration \\
\hline Screen size & $\begin{array}{l}\text { Smartphone (3 to 5 inches), 11 studies } \\
\text { Tablet (6 to 12 inches), 11 studies } \\
\text { Monitor (15 to 19 inches), 9 studies } \\
\text { Surface (24 to 42 inches, horizontal), 3 studies [Apted et al. 2006; } \\
\text { Piper et al. 2010; Vetter et al. 2011] }\end{array}$ \\
\hline Screen resolution & $\begin{array}{l}\text { Some examples of variability of display dimensions: 240x320 or } \\
640 x 960 \text { on 3.5 inches screen [Hourcade and Berkel 2006; } \\
\text { Kobayashi et al. 2011], 768x1024 or 870x1152 on 9.7 inches screen } \\
\text { [Kobayashi et al. 2011; Findlater et al. 2013]. }\end{array}$ \\
\hline Touchscreen technology & $\begin{array}{l}\text { 3 studies used resistive touchscreens [Wood et al. 2005; Leonard et } \\
\text { al. 2005; Wright et al. 2000]. Most of studies after 2006 should } \\
\text { have used capacitive touchscreens. }\end{array}$ \\
\hline Screen orientation & $\begin{array}{l}\text { Portrait, 13 studies } \\
\text { Landscape, 13 studies } \\
\text { Not-specified, 4 studies }\end{array}$ \\
\hline Device orientation & $\begin{array}{l}\text { Horizontal (0 to 30 }), 11 \text { studies, } \\
\left.\text { Vertical (75 to 90 } 90^{\circ}\right) \text {, 10 studies, } \\
\text { Not-specified or not applied, 9 }\end{array}$ \\
\hline Device position & $\begin{array}{l}\text { Handheld, 5 studies } \\
\text { Fixed, 17 studies } \\
\text { Non-mentioned, } 8\end{array}$ \\
\hline
\end{tabular}

Commonly, touchscreen support pen or fingers interaction. Only one study compared the performances between these two input devices[Hourcade and Berkel 2006]. Some studies compare direct interaction with indirect input, as shown by theTable 5. The gestures of interaction are described and analyzed on section 4.4.

Table 5. Studies reviewed that compared direct and indirect input devices ${ }^{1}$.

\begin{tabular}{|l|l|}
\hline Direct input & Indirect input \\
\hline Finger interaction on touchscreen & Mouse, enlarged mouse, touch pad \\
& [Wood et al. 2005] \\
& Mouse,eye-gaze input \\
& [Schneider et al. 2008] \\
& Physical keypad (for digit input tasks) \\
& [Chung et al. 2010] \\
& Physical keyboard (for text-entry tasks) \\
& {$[$ Umemuro 2004] } \\
\hline Pen interaction on touchscreen & RFID-based interface \\
& {$[$ Iglesias et al. 2009] } \\
& Mouse \\
& [Jastrzembski et al. 2005; Charness et al. 2004] \\
& Rotary encoder \\
& {$[$ Rogers et al. 2005] } \\
& Physical keyboard (for text-entry tasks) \\
& [Wright et al. 2000] \\
\hline
\end{tabular}

${ }^{1}$ According to the definition of Rogers et al (2005) [51], direct input devices don't require any translation between the user's action and this action on the system. Indirect input devices, on the other hand, use different dimensions (for example, scale of movement). 


\subsubsection{Discussion}

The studies have evaluated interaction on devices with different screen sizes, screen resolution and touchscreen technologies. Different screen positions and orientation were used. Two studies compared interaction on different screen sizes, but all the other parameters affecting the layout display and the interaction need to be further studied.

In summary, results show that larger screen sizes were related to better performances because it displays bigger keys size and inter-spacing [Umemuro 2004; Kobayashi et al. 2011]. Results of a study with younger adults showed that touch interaction on vertical or horizontal surfaces induces different performances and fatigue [Pedersen and Hornbæk 2012]. No problems were reported for older users with low manual dexterity to interact with large horizontal touchscreens [Apted et al. 2006; Piper et al. 2010].

Designers should consider the possibilities of choice of devices. Ideally, systems should be adaptive: layout should correctly fit into different screen sizes and allow interaction with different input techniques, so users would be able of using or accessing information through different devices.

\subsection{Tasks}

\subsubsection{Description}

All the studies allowed practice trials before the experiment. Longer familiarization periods where proposed for participants without previous experience with touchscreen (half-day to one week period). Training tasks are detailed on theTable 6.

Table 6. Training tasks on the studiesreviewed.

\begin{tabular}{|l|l|}
\hline Kind of training & Number of studies and details \\
\hline Familiarization period & $\begin{array}{l}\text { 2 studies } \\
\text { [Kobayashi et al. 2011; Harada et al. 2013] }\end{array}$ \\
\hline Practice trials & $\begin{array}{l}10 \text { studies } \\
\text { [Chung et al. 2010; Hourcade and Berkel 2006; Hwangbo et al. 2013; } \\
\text { Jin et al. 2007; Leonard et al. 2005; Lepicard and Vigouroux 2010a; } \\
\text { Lepicard and Vigouroux 2010b; Lepicard and Vigouroux 2012; } \\
\text { Nicolau and Jorge 2012; Tsai and Lee 2009] }\end{array}$ \\
\hline $\begin{array}{l}\text { 2 studies } \\
\text { [Leitao and Silva 2013; Harada et al. 2013] }\end{array}$ \\
\hline Demonstration & $\begin{array}{l}\text { 1 study } \\
\text { [Apted et al. 2006] }\end{array}$ \\
\hline Printed tutorial
\end{tabular}

Tutorials and training can be used to help older adults, improving their performances and positively influencing their attitudes towards touchscreens [Leitao and Silva 2013]. Older adults show better performances and stabilization after the $20^{\text {th }}$ trial [Mertens and Jochems 2010]. A week experience improved performances of interaction especially for dragging and pinching gestures [Kobayashi et al. 2011]. Familiar user interfaces and simple tasks are helpful to start [Hwangbo et al. 2013].

Subjects worked on groups during some studies [Apted et al. 2006; Gonçalves et al. 2011; Harada et al. 2013]. Working in pairs can be useful for older users because they can learn by observing their partners [Apted et al. 2006; Gonçalves et al. 2011; Harada et al. 2013]. It can also generate more natural situations during the experiment.

The main tasks can be elementary or complex: the first ones had simple layout (few or no distractors) and users should do one single task at the time. Complex tasks, on the 
other hand, were composed of several sub-tasks and represented more realistic situations.

Elementary tasks like reading, selecting targets, typing (text, digit or passwords) or executing patterns of gestures on the touchscreen were evaluated, as described on theTable 7.

Table 7 Elementary tasks on the studiesreviewed.

\begin{tabular}{|l|l|}
\hline Elementary tasks & Number of studies and details \\
\hline Reading & $\begin{array}{l}3 \text { studies } \\
\text { [Hollinworth 2009; Nischelwitzer and Pintoffl 2007; Piper et al. } \\
2010]\end{array}$ \\
\hline Target selection & 12 studies \\
\hline Text or digit input & 11 studies \\
\hline Patterns of gestures & 9 studies \\
\hline
\end{tabular}

Only three studies evaluate reading tasks by older users. Reading tasks consist on the evaluation of text fonts, comfort and also the interaction technique for scrolling, passing through pages and resizing the texts. While reading, participants appreciate when they can adjust font size [Hollinworth 2009]. The inclination of the screen can be uncomfortable [Piper et al. 2010]. Authors recommend limiting the number of lines of text [Nischelwitzer and Pintoffl 2007] and avoid scrolling because certain users can loss orientation between lines [Apted et al. 2006]. Arrows buttons can help users go forward or backward as books pages.

Target selection tasks and typing are affected by targets sizes, spacing and location, on small touchscreen devices [Hwangbo et al. 2013] and also on larger screen sizes [Lepicard and Vigouroux 2010b]. Results of the experiments show that it is better to reduce the number of targets [Hourcade and Berkel 2006; Jin et al. 2007; Lepicard and Vigouroux 2010b]. 4 or 6 targets are easier to identify and interact than 8, especially for users aged 70 years old or more [Lepicard and Vigouroux 2010a]. Placing targets near to the boundaries helps motor impaired users and facilitate long gestures of interaction for target selection or text entry [Mertens and Jochems 2010]. 8 targets or more showed better results when placed into two blocks, on the left and the right side of the screen. Two hands interaction can be used on this situation [Lepicard and Vigouroux 2010a]. Pen interaction allows smaller targets, even $3 \mathrm{~mm}$ width targets for older users with high manual dexterity [Moffatt and McGrenere 2007]. Concerning the targets location on small screen devices, movements from top to bottom are easier to visually impaired older users according to [Apted et al. 2006] and diagonal movements are slower, so designers should consider upper-bottom or side directions of a center point [Hwangbo et al. 2013].

Familiarity to the interfaces is important for typing tasks. Number entry is easier with explicit displays, such as numeric keypads instead of cursors or sliders [Nischelwitzer and Pintoffl 2007]. Sliders can be used when there are few options to select, with pre-defined positions. For numeric keypads, the zero key should be placed at the bottom, in the middle (under the "8") [Nischelwitzer and Pintoffl 2007; Chung et al. 2010; Harada et al. 2013]. Labelling the space bar would be helpful for less experienced users [Piper et al. 2010].

Authors recommend to address the gap between the intended and the actual touch location [Kobayashi et al. 2011; Nicolau and Jorge 2012; Harada et al. 2013]. Soft keyboards can be calibrated to adapt to users' special needs, correcting drifting for 
example [Nicolau and Jorge 2012]. It is also possible to adapt soft keyboard presentation [Umemuro 2004; Nicolau and Jorge 2012], highlighting letters according to the text that has already been inserted. Word prediction and spelling correctors should also help older users during text entry tasks, especially older users with tremors [Nicolau and Jorge 2012; Wright et al. 2000]. Authors also recommend to provide support for slipping, a common error between older users [Hourcade and Berkel 2006; Moffatt and McGrenere 2007].

Large patterns are faster to execute during single-touch gestures with finger interaction [Stößel et al. 2010]. Authors recommend to avoid acute angles and use familiar shapes [Stößel 2009]. When using patterns of gestures of interaction with one finger on single touch devices, it is recommended to avoid complex patterns [Vetter et al. 2011].

Ten studies proposed multiple elementary tasks during the execution of one complex exercise. It allows the analysis of interaction as a whole on more realistic situations. The kind of complex exercises analyzed by these studies is detailed on Table 8Table .

Table 8 Complex exercises (tasks with several sub-tasks) on the studiesreviewed.

\begin{tabular}{|l|l|}
\hline Complex exercises & Number of studies and details \\
\hline Use a digital agenda & $\begin{array}{l}\text { 1 study } \\
\text { [Iglesias et al. 2009], }\end{array}$ \\
\hline Email & $\begin{array}{l}\text { 2 studies } \\
\text { [Hollinworth 2009; Umemuro 2004] }\end{array}$ \\
\hline Phone tasks & $\begin{array}{l}\text { 2 studies } \\
\text { [Gonçalves and Ueyama 2012; Harada et al. 2013] }\end{array}$ \\
\hline Photo manipulation & $\begin{array}{l}\text { 1 study } \\
\text { [Apted et al. 2006] }\end{array}$ \\
\hline Health care systems & 2 studies \\
& [Piper et al. 2010; Nischelwitzer and Pintoffl 2007] \\
\hline Map visualization & 1 study \\
& [Harada et al. 2013] \\
\hline
\end{tabular}

\subsubsection{Discussion}

Learning how to interact with new technologies and using a new interaction technique can be demanding on time and practice [Mertens and Jochems 2010]. Familiarization with the gestures of interaction and with the layout is especially important for novice users. Otherwise, systems should provide cues for interaction in order to facilitate initial learning (i.e. animations, pop-up frames with description or visual cues).

Complex exercises allow the observation of more usual situations as well as the subjective analysis of the participants, their common errors and difficulties. Systems should be usable and accessible through all the different tasks. Target selection concerns the use of soft keys for typing text or digits. Reading may concern text entry tasks and controlling the display.

Recommendations for the use ofdifferent layout configurations and interaction techniques are directly related to the tasks executed on the reviewed studies. However, it is possible to cross recommendations. For example, Iglesias et al (2009) could verify that icons were better than images for representing actions and movement on an agenda [Iglesias et al. 2009]. This recommendation can also be used on other systems and applications. Leonard et al (2005) recommends to reduce the number of distractors 
[Leonard et al. 2005]; it concerns not only visually impaired people but older users in general.

Future work should consider the passing between tasks and get closer to more realistic situations, in order to prevent errors or supplementary manipulation. Usercentered design approaches provide important information to improve accessibility and usability of systems destined to older users.

\subsection{Interaction techniques}

Different interaction techniques can be used to access information and communicate with an interactive system. Different input modalities have been evaluated, with pen or fingers and single or multi-touch interaction. Several gestures of interaction have also been studied, the most current as "tapping" and "dragging" or new ways of typing as "swabbing". Multimodal output have been provided and evaluated, including visual feedback on the touchscreen display or audio and tactile feedback.

The distinction between input and output interfaces on this section is made purely for analytical purposes. Input and output are completely interlaced and they cannot be designed independently [Nigay and Coutaz 1996].

\subsubsection{Input}

\subsubsection{Description}

The studies evaluated pen or finger interaction on single or multi-touch systems. Seven studies investigated the use of pen based interaction by older users. One study compared pen or finger interaction [Hourcade and Berkel 2006]. Twenty-seven studies evaluated tactile interaction with fingers.

Table 9synthetizes the input techniques investigated by these studies. Twenty-seven studies evaluated single-touch interaction. Seven studies evaluated multi-touch interaction [Apted et al. 2006; Findlater et al. 2013; Lepicard and Vigouroux 2012; Leitao and Silva 2013; Piper et al. 2010; Kobayashi et al. 2011; Harada et al. 2013]. One study compared single and multi-touch interaction for older users [Lepicard and Vigouroux 2012].

Table 9. Input techniques investigated on the studiesreviewed.

\begin{tabular}{|l|l|l|}
\hline $\begin{array}{l}\text { Input modalities / } \\
\text { pumber of touch } \\
\text { points }\end{array}$ & Single-touch & Multi-touch \\
\hline Pen & $\begin{array}{l}7 \text { studies } \\
\text { [Hourcade and Berkel } \\
2006 ; \text { Leonard et al. 2005; } \\
\text { Moffatt and McGrenere } \\
\text { 2007; Wright et al. 2000; } \\
\text { Charness et al. 2004; } \\
\text { Jastrzembski et al. 2005; } \\
\text { Rogers et al. 2005] }\end{array}$ & $\begin{array}{l}\text { No studies evaluated or proposed pen } \\
\text { and multi-touch }\end{array}$ \\
& $\begin{array}{l}20 \text { studies } \\
\text { Finger }\end{array}$ & $\begin{array}{l}\text { One hand, 5 studies } \\
\text { [Findlater et al. 2013; Leitao and Silva } \\
\text { 2013; Harada et al. 2013; Lepicard and } \\
\text { Vigouroux 2012; Kobayashi et al. } \\
\text { 2011] } \\
\text { Two hands, 2 studies [Lepicard and } \\
\text { Vigouroux 2012; Piper et al. 2010] }\end{array}$ \\
\hline
\end{tabular}


Concerning finger interaction, it has been reported that most of users used the index finger to pointing and target selection tasks, as well as text or digit entry tasks. Sometimes, they have been asked to interact with this precise finger. New studies have been done to evaluate interaction with thumbs or others fingers by young or middle aged adults [Wagner et al. 2012], but it has not been evaluated with older adults yet.

Pen interaction could be helpful for older users with motor difficulties, as shown by previous studies that have considered pen-based interaction for motor impaired young people [Cofre et al. 2012]. The contact of the pen with the screen seems to be easier to control and it does not hide a big surface on the screen, in contrary to fingers gestures or multi-touch interaction.

Multi-touch interaction is current used on most of devices and some gestures are needed to execute some functions on tablets and smartphones. Unfortunately, to the best of our knowledge, few studies evaluated multi-touch interaction of older adults. Only two studies analyzed common gestures as scroll, pan, pinch or rotate [Harada et al. 2013; Leitao and Silva 2013]. Multi-touch gestures have only been studied with ablebodied participants.

During the evaluation of gestures of interaction, authors compared the time of the trial and time of completion, accuracy and errors. For evaluation the execution of patterns of gestures, displacements and boundaries were used on one study[Stößel et al. 2010] and drag distance in another[Wood et al. 2005]. Subjective difficulties and appreciation are also reported [Lee et al. 2009]. When evaluating interfaces, authors compared target sizes and spacing, the positions of interactive zones on the screen, icon recognition and preferences.

Table 10synthetizes the main gestures of interaction evaluated on these studies.For analytical purposes, we have divided gestures into two kinds: target selection, one single touch on one specific target, and displacement, a continuous touch on the screen from an initial to a final position.

Table 10. Main gestures of interaction evaluated on thestudiesreviewed.

\begin{tabular}{|l|l|l|l|}
\hline Touch kind & $\begin{array}{l}\text { Kind of touch } \\
\text { gesture }\end{array}$ & Examples & $\begin{array}{l}\text { Studies that used/evaluated this } \\
\text { interaction technique by older } \\
\text { adults }\end{array}$ \\
\hline Single-touch & Target selection & Tap, type & $\begin{array}{l}\text { 6 studies } \\
\text { [Gonçalves and Ueyama 2012; } \\
\text { Chung et al. 2010; Lee et al. 2009; } \\
\text { Harada et al. 2013; Wright et al. } \\
\text { 2000; Nicolau and Jorge 2012] }\end{array}$ \\
\hline Single-touch & Displacement & $\begin{array}{l}\text { Drag, move, draw, } \\
\text { scroll, pan, swipe, } \\
\text { swab, steer }\end{array}$ & $\begin{array}{l}\text { [ studies } \\
\text { [indlater et al. 2013; Leitao and } \\
\text { Silva 2013; Lepicard and Vigouroux } \\
\text { 2012; Wood et al. 2005; Stößel et al. } \\
\text { 2010; Harada et al. 2013; Mertens } \\
\text { and 20chems } \\
\text { Wacharamanotham 2011] }\end{array}$ \\
\hline Multi-touch & Target selection & - & - \\
& & & \\
\hline
\end{tabular}




\begin{tabular}{|l|l|l|l|}
\hline Multi-touch & Displacement & $\begin{array}{l}\text { Rotate, spread, } \\
\text { pinch }\end{array}$ & $\begin{array}{l}\text { 8 studies } \\
\text { [Findlater et al. 2013; Lepicard and } \\
\text { Vigouroux 2012; Leitao and Silva } \\
\text { 2013; Harada et al. 2013; Piper and }\end{array}$ \\
& & $\begin{array}{l}\text { Hollan 2013; Apted et al. 2006; } \\
\text { Hollinworth and Hwang 2011; } \\
\text { Kobayashi et al. 2011] }\end{array}$ \\
\hline
\end{tabular}

\subsubsection{Discussion}

Existing interaction techniques are evaluated, as selecting targets with one simple direct touch, moving or dragging objects, typing text or digits. New techniques being developed have also been proposed, as the execution of patterns of gestures or other long touch movements, such as swabbing, that has shown efficiency of use for users with tremor [Wacharamanotham 2011].

Gestures for tactile interaction can be characterized by their distance (initial and final position, trajectory), duration (short time or holding) and direction. The number of points of contact and the position of the hand and fingers can also be used to elaborate new ways of interaction. For instance no studies evaluated this possibility for older users. On this analysis, target selection with multi-touch gestures should be proposed for older adults, as it has already been employed for selecting commands and menus[Bailly et al. 2012].

Some familiar gestures have not yet been studied, as handwriting. Although, it has been mentioned and would be useful for pen-based interaction[Hollinworth and Hwang 2011].

Ideally, systems should support single or multi-touch interaction with pen and fingers, according to the choice of the users or their possibilities of use. Users adapt themselves and have different strategies, especially observed for scrolling, panning and zooming. User-defined gestures have not yet been proposed to older users.

More studies need to be done to identify older user's difficulties when executing current gestures of interaction, especially users with low manual dexterity or motor impairments. Interface adaptation and support for interaction should help older users interacting with touchscreen devices.

\subsubsection{Output}

\subsubsection{Description}

All studies except one provided visual feedback during touchscreen interaction. The only exception is a study about repeating patterns of gestures, where participants received no visual marks of the drawn trajectories to avoid corrective movements during the task [Stößel et al. 2010].

One study evaluated the effects of providing different visual feedback during a digit entry task: 3 visual effects were applied on soft keys (magnifying, movement, changing color) and this effects were evaluated alone or combined [Tsai and Lee 2009].

Table Table 11synthetizes the kind of feedback provided to the users. Five studies provided audio feedback. three of them played a beep sound when the users misses the target [Moffatt and McGrenere 2007], entry a wrong number [Chung et al. 2010] or to indicate a correct selection [Hwangbo et al. 2013]. One provided audio aids when users selected the icons [Iglesias et al. 2009]. The other played a message when the user accomplished the task (thanking for the participation) [Gonçalves and Ueyama 2012]. 
Only two studies evaluate the bi-modality visual-tactile feedback or tri-modality visual-audio-tactile feedback for older users [Hwangbo et al. 2013; Lee et al. 2009].

Table 11. Kind of feedback provided on the studiesreviewed.

\begin{tabular}{|l|l|}
\hline Feedback modality & Number of studies \\
\hline Visual & $\begin{array}{l}\text { All studies provided visual feedback except one [Stößel et al. 2010], } \\
1 \text { study evaluated different modalities of visual feedback [Tsai and } \\
\text { Lee 2009] }\end{array}$ \\
\hline Visual + Audio & $\begin{array}{l}5 \text { studies: Beep sound for errors [Moffatt and McGrenere 2007; } \\
\text { Chung et al. 2010; Hwangbo et al. 2013], beep sound for } \\
\text { confirmation, a message for accomplishment [Gonçalves and } \\
\text { Ueyama 2012] or audio aids [Iglesias et al. 2009] }\end{array}$ \\
\hline Visual + Tactile & $\begin{array}{l}3 \text { studies: 2 studies evaluated interaction with or without tactile } \\
\text { feedback [Lee et al. 2009; Hwangbo et al. 2013]. 1 study had a } \\
\text { vibration effect for accomplishment [Gonçalves and Ueyama 2012] }\end{array}$ \\
\hline Visual + Audio + Tactile & $\begin{array}{l}\text { 2 studies investigated tri-modality [Lee et al. 2009; Hwangbo et al. } \\
\text { 2013] }\end{array}$ \\
\hline
\end{tabular}

\subsubsection{Discussion}

Feedback was used to indicate and prevent errors and help the interaction. Authors reported that visual feedback should be explicit and support the interaction.

Visual feedback would help users to know if the correct target has been touch [Kobayashi et al. 2011]. Magnifying effects on icons or keys for example allows the user to verify the place of touch during the interaction[Tsai and Lee 2009]. An important remark has been made that visual feedback should indicate the current screen mode [Kobayashi et al. 2011; Harada et al. 2013].

Auditory feedback may be a valuable non-visual cue for support gestures of interaction [Leonard et al. 2005]. It has already been proved to improve pointing performances on touchscreen [Hwangbo et al. 2013].

Tactile feedback has been considered distracting for novice older users [Hwangbo et al. 2013] or less effective than audio feedback [Lee et al. 2009], but more studies need to be done in order to evaluate different patterns and vibration intensity according to the sensitivity of the users' skin. Vibration should compensate lack of tactile feedback on flat displays [Umemuro 2004].

Due to the age related changes on sensorial skills, multimodal feedback could provide alternatives and complementary feedback in order to support touchscreen interaction. Only two studies have evaluated the effects of multimodal feedback during target selection and digit input tasks on small screens by older users without disabilities [Hwangbo et al. 2013; Lee et al. 2009]. More studies need to be done to improve multimodal feedback.

\section{DISCUSSION}

Several works concerning HCI of older adults have been done, revealing the importance researchers of different fields of knowledge have been giving to this subject. Between 2000 and 2013, studies about tactile interaction of older adults featured two main situations: the evaluation of the usability of different interaction techniques, for specific tasks or situations of use; or the evaluation of the usability of one interactive system, through user-centered design methods. However, new interaction techniques, 
applications and devices are been developed and continuously launched into the market, so more studies have to be done to improve existing techniques and propose new ones. Since 2014, a new set of studies about older adults and tactile interaction emerged. Researchers started to get interested in the variability of this population and the voids of usability, accessibility and ergonomics of the interaction with new technologies. It has been demonstrated that experience of use and cognitive capabilities are more significant than age as predictors of use of technologies [Crabb and Hanson 2014]. Concerning tactile interaction, support techniques for novice older adults have been created and evaluated [Dahn et al. 2014]. Some studiesalso showed interest in the abilities of older users as producers of interaction and the way they conceive technologies use [Rogers et al. 2014].

However, in order to address the difficulties older users face during interaction with technologies, usability and accessibility of mobile devices need to be improved. The state of the art we presented demonstrates that it is difficult to take into account the heterogeneity of older adults as well as the new situations of use of mobile devices and touchscreen. Even if the existing studies provide important recommendations, older adults' common errors and mistakes should be further investigated in order to provide information for developing adequate solutions.

\section{CONCLUSION}

The accomplishment of the touchscreen interaction depends on several parameters related to skills of the users, their previous experiences and background, as well as the interaction technique that is used, the graphical user interface, the apparatus configuration and the situation of use.

As this review has described, individual characteristics of older users, the variability of devices and multiple situations of use have been taken into account during studies evaluating tactile interaction but further studies need to be done in order to improve existing interaction techniques and also to propose new ones, more adapted to the older user's special needs.

These multiple parameters should be taken into account

- When using existing guidelines. They are valuable and helpful, but they are related to the conditions of the study (population included, devices configuration, executed tasks).

- When making new studies. The evolution of the population characteristics and the new technologies and interaction techniques is a challenge for developers and designers.

Interactive systems should be able to respond to different configurations and support the behavior of the users. The possibility of adapting the gestures of interaction and the graphical user interface to respond to the users'special needs is an advantage of touchscreen devices that has not yet been totally employed on the profit of older users.

New guidelines should facilitate the development of more accessible, ergonomic and user-friendly applications so older people could benefit of touchscreen devices, preventing digital exclusion and improving quality of life for this group of users. 


\section{ACKNOWLEDGEMENT}

Phd Scholarship Ciências sem fronteiras, CNPQ, Brazil (\#237079/2012-7).

\section{LIST OF THE 36 STUDIES INCLUDED ON THIS REVIEW}

1. APTED, T., KAY, J. AND QUIGLEY, A., 2006. Tabletop sharing of digital photographs for the elderly. CHI'06 (ACM), pp.781-790.

2. CHUNG, M.K., KIM, D., NA, S. AND LEE, D., 2010. Usability evaluation of numeric entry tasks on keypad type and age. International Journal of Industrial Ergonomics, 40(1), pp.97-105.

3. FINDLATER, L., FROEHLICH, J.E., FATTAL, K., WOBBROCK, J.O. AND DASTYAR, T., 2013. Age-related differences in performance with touchscreens compared to traditional mouse input. CHI'13 (ACM), pp.343346.

4. GONÇALVES, V.P. AND UEYAMA, J., 2010. Um Estudo sobre o Design , a Implementação e a Avaliação de Interfaces Flexíveis para Idosos em Telefones Celulares. Simposio Brasileiro de Fatores Humanos.

5. GUERREIRO, T., NICOLAU, H., JORGE, J. AND GONÇALVES, D., 2010. Towards accessible touch interfaces. Proceedings of the 12th international ACM SIGACCESS conference on Computers and accessibility - ASSETS '10, p.19.

6. HARADA, S., SATO, D., TAKAGI, H. AND ASAKAWA, C., 2013. Characteristics of Elderly User Behavior on Mobile Multi-touch Devices. INTERACT'13, pp.323-341.

7. HOLLINWORTH, N. AND HWANG, F., 2011. Investigating familiar interactions to help older adults learn computer applications more easily. BCSHCI'11.

8. HOLZINGER, A., 2003. Finger Instead of Mouse : Touch Screens as a Means of Enhancing Universal Access 3 A Vision : Computers for Patient Education., (July 2002), pp.387-397.

9. HOURCADE, J. AND BERKEL, T., 2006. Tap or touch?: pen-based selection accuracy for the young and old. CHI'06, pp.881-886.

10. HWANGBO, H., YOON, S. AND JIN, B., 2013. A study of pointing performance of elderly users on smartphones. International Journal of HumanComputer Interaction, 29(9), pp.1-10.

11. IGLESIAS, R., GOMEZ DE SEGURA, N. AND ITURBURU, M., 2009. The elderly interacting with a digital agenda through an RFID pen and a touch screen. ACM SIGMM MSIADU '09, p.63.

12. JASTRZEMBSKI, T., CHARNESS, N., HOLLEY, P. AND FEDDON, J., 2005. Input devices for web browsing: age and hand effects. Universal Access in the Information Society, 4(1), pp.39-45.

13. JIN, Z.X., PLOCHER, T. AND KIFF, L., 2007. Touch Screen User Interfaces for Older Adults : Button. UAHCI'07, pp.933-941.

14. KOBAYASHI, M., HIYAMA, A. AND MIURA, T., 2011. Elderly user evaluation of mobile touchscreen interactions. INTERACTS (2011), pp.83-99.

15. LEE, J., POLIAKOFF, E. AND SPENCE, C., 2009. The effect of multimodal feedback presented via a touch screen on the performance of older adults. M.E. 
Altinsoy, U. Jekosch, and S. Brewster (Eds.): HAID 2009, LNCS 5763, pp.128-135.

16. LEITAO, R. AND SILVA, P., 2013. A study of novice older adults and gestural interaction on smartphones. CHI'13 (ACM).

17. LEONARD, V.K., JACKO, J. A. AND PIZZIMENTI, J.J., 2005. An exploratory investigation of handheld computer interaction for older adults with visual impairments. Proceedings of the 7th international ACM SIGACCESS conference on Computers and accessibility - Assets '05, pp.1219.

18. LEPICARD, G. AND VIGOUROUX, N., 2012. Comparison between singletouch and multi-touch interaction for older people. ICCHP'12 Computers Helping People with Special Needs, pp.658-665.

19. LEPICARD, G. AND VIGOUROUX, N., 2010a. Influence of age and interaction complexity on touch screen Color and position effects on user performance. 12th IEEE International Conference on e-Health Networking Applications and Services (Healthcom), pp.246 - 253.

20. LEPICARD, G. AND VIGOUROUX, N., 2010b. Touch Screen User Interfaces for Older Subjects Effect of the Targets Number and the Two Hands Use. K. Miesenberger et al. (Eds.): ICCHP 2010, Part II, LNCS 6180, pp.592599.

21. MERTENS, A. AND JOCHEMS, N., 2010. Design pattern TRABING: touchscreen-based input technique for people affected by intention tremor. ACM SIGCHI EICS (2010), pp.267-272.

22. MOFFATT, K. AND MCGRENERE, J., 2007. Slipping and drifting: using older users to uncover pen-based target acquisition difficulties. In Proceedings of the 9th international ACM ASSETS. October 15-17, 2007, Tempe, Arizona, pp. 11-18.

23. NICOLAU, H. AND JORGE, J., 2012. Elderly text-entry performance on touchscreens. Proceedings of the 14th international ACM SIGACCESS conference on Computers and accessibility - ASSETS '12, p.127.

24. NISCHELWITZER, A. AND PINTOFFL, K., 2007. Design and development of a mobile medical application for the management of chronic diseases: methods of improved data input for older people. USAB'07, pp.119-132.

25. PIPER, A.M., CAMPBELL, R. AND HOLLAN, J.D., 2010. Exploring the accessibility and appeal of surface computing for older adult health care support. Proceedings of the 28th international conference on Human factors in computing systems - CHI '10, p.907.

26. PIPER, A.M. AND HOLLAN, J.D., 2011. Supporting medical communication for older patients with a shared touch-screen computer. International Journal of Medical Informatics, 82(11), pp.e242-e250.

27. ROGERS, W. A, FISK, A.D., MCLAUGHLIN, A.C. AND PAK, R., 2005. Touch a screen or turn a knob: choosing the best device for the job. Human factors, 47(2), pp.271-88.

28. SCHNEIDER, N., WILKES, J.A., GRANDT, M. AND SCHLICK, C., 2008. Investigation of Input Devices for the Age-differentiated Design pf HumanComputer Interaction. In Human factors and Ergonomics Society 52nd annual meeting. pp. 144-148. 
29. STÖßEL, C., 2009. Familiarity as a factor in designing finger gestures for elderly users. Proceedings of the 11th International Conference on HumanComputer Interaction with Mobile Devices and Services - MobileHCI '09, p.1.

30. STÖßEL, C., WANDKE, H. AND BLESSING, L., 2010. Gestural interfaces for elderly users: help or hindrance? GW 2009, pp.269-280.

31. TSAI, W. AND LEE, C., 2009. A study on the icon feedback types of small touch screen for the elderly. Universal Access in Human-Computer Interaction., pp.422-431.

32. UMEMURO, H., 2004. Lowering elderly Japanese users? resistance towards computers by using touchscreen technology. Universal Access in the Information Society, 3(3-4), pp.276-288.

33. VETTER, S., BÜTZLER, J., JOCHEMS, N. AND SCHLICK, C., 2011. Fitts' Law in Bivariate Pointing on Large Touch Screens: Age-Differentiated Analysis of Motion Angle Effects on Movement Times and Error Rates. UAHCI'11, pp.620-628.

34. WACHARAMANOTHAM, C., 2011. Evaluating swabbing: a touchscreen input method for elderly users with tremor. CHI'11, ACM, pp.623-626.

35. WOOD, E., WILlOUGHBY, T., RUSHING, A., BECHTEL, L. AND GILBERT, J., 2005. Use of computer input devices by older adults. Journal of Applied Gerontology, 24(5), pp.419-438.

36. WRIGHT, P., BARTRAM, C., ROGERS, N. AND EMSLIE, H., 2000. Text entry on handheld computers by older users. Ergonomics, 43:6(May 2013), pp.37-41.

\section{REFERENCES}

Al-Razgan, M.S., Al-Khalifa, H.S., Al-Shahrani, M.D. AND Alajmi, H.H., 2012. Touch-based mobile phone interface guidelines and design recommendations for elderly people: A survey of the literature. In 19th International Conference ICONIP 2012, Part IV, nov. 2012. pp. 568-574.

APTED, T., KAY, J. AND QUIGLEY, A., 2006. Tabletop sharing of digital photographs for the elderly. ACM CHI'06, pp.781-790.

Bailly, G., Müller, J. AND LeColinet, E., 2012. Design and evaluation of fingercount interaction: Combining multitouch gestures and menus. International Journal of Human-Computer Studies, 70(10), pp.673-689.

CAPRANi, N., O'CONNOR, N. AND GURRIN, C., 2012. Touch screens for the older user. In Fernando A. Auat Cheein, ed. Assistive Technologies, InTech.

Charness, N., Holley, P., Feddon, J. And JASTRZEMBSKi, T., 2004. Light pen use and practice minimize age and hand performance differences in pointing tasks. Human factors and Ergonomics Society, 46(3), pp.373-84.

CHUnG, M.K., KIM, D., NA, S. AND LEE, D., 2010. Usability evaluation of numeric entry tasks on keypad type and age. International Journal of Industrial Ergonomics, 
40(1), pp.97-105.

Cofre, J.P., Moraga, G., Rusu, C., Mercado, I., Inostroza, R. and Jimenez, C., 2012. Developing a Touchscreen-based Domotic Tool for Users with Motor Disabilities. 2012 Ninth International Conference on Information Technology New Generations, pp.696-701.

Crabb, M. And Hanson, V.L., 2014. Age, Technology Usage , and Cognitive Characteristics in Relation to Perceived Disorientation and Reported Website Ease of Use. In ASSETS'14. Rochester, NY, USA: ACM, pp. 193-200.

Dahn, I., Ferdinand, P. And Lachmann, P., 2014. Supporting Senior Citizen Using Tablet Computers. In K. Miesenberger et al., ed. ICCHP 2014, Part II, LNCS 8548. Paris, France: Springer, pp. 323-330.

Dickinson, A., ARnOtT, J. AND PRIOR, S., 2007. Methods for human - computer interaction research with older people. Behaviour \& Information Technology, 26:4(May 2013), pp.343-352.

Findlater, L., Froehlich, J., FAtTal, K., Wobbrock, J.O. AND Dastyar, T., 2013. Age - Related Differences in Performance with Touchscreens Compared to Traditional Mouse Input. In CHI'13. pp. 1-4.

Gonçalves, V., Neris, V.P.A. AND Ueyama, J., 2011. Interação de idosos com celulares: flexibilidade para atender a diversidade. Proceedings of IHC +CLIHC'2011 - Technical Session on HCI and the elderly, pp.343-352.

GONÇALVES, V.P. AND UEYAMA, J., 2012. Um Estudo sobre o Design, a Implementação e a Avaliação de Interfaces Flexíveis para Idosos em Telefones Celulares. Simposio Brasileiro de Fatores Humanos.

Gudur, R.R., Blackler, A., Popovic, V. And Mahar, D., 2013. Ageing, technology anxiety and intuitive use of complex interfaces. In P. Kotzé et al., ed. INTERACT 2013, Part III, LNCS 8119. IFIP, pp. 564-581.

HANSON, V., 2009. Age and web access: the next generation. In 18th International World Wide Web Conference W4A2009. April 20-21, 2009, Madrid, Spain, pp. 7 15.

Harada, S., Sato, D., TAKagi, H. AND AsaKawa, C., 2013. Characteristics of Elderly User Behavior on Mobile Multi-touch Devices. P. Kotzé et al. (Eds.): INTERACT 2013, Part IV, LNCS 8120, pp.323-341.

HOLLINWORTH, N., 2009. Improving computer interaction for older adults. ACM SIGACCESS Accessibility and Computing, (93), pp.11-17.

HOLlinwORTH, N. AND HwANG, F., 2011. Investigating familiar interactions to help 
older adults learn computer applications more easily. In BCS-HCI'11. pp. 473478.

HolzINGER, A., 2003. Finger Instead of Mouse: Touch Screens as a Means of Enhancing Universal Access. In N. Carbonell and C. Stephanidis, ed. User Interfaces for All, LNCS 2615. Springer-Verlag Berlin Heidelberg, pp. 387-397.

HOURCADE, J.P. AND BERKEL, T., 2006. Tap or touch?: pen-based selection accuracy for the young and old. $A C M C H I^{\prime} 06, \mathrm{pp} .881-886$.

Hwangbo, H., Yoon, S.H., Jin, B.S., Han, Y.S. AND Ji, Y.G., 2013. A Study of Pointing Performance of Elderly Users on Smartphones. International Journal of Human-Computer Interaction, 29(9), pp.604-618.

Iglesias, R., Gomez De Segura, N. AND Iturburu, M., 2009. The elderly interacting with a digital agenda through an RFID pen and a touch screen. ACM SIGMM $i$ MSIADU '09, p.63.

IJSSElsteIJn, W., NAP, H.H., DE KORT, Y. AND POELS, K., 2007. Digital game design for elderly users. Proceedings of the 2007 conference on Future Play - Future Play '07, 15-17 novembre 2007, Toronto, Canada., pp.17-22.

Jastrzembski, T., Charness, N., Holley, P. And Feddon, J., 2005. Input devices for web browsing: age and hand effects. Universal Access in the Information Society, 4(1), pp.39-45.

JiN, Z.X., Plocher, T. AND KIFF, L., 2007. Touch Screen User Interfaces for Older Adults : Button Size and Spacing. C. Stephanidis (Ed.): Universal Access in HCI, Part I, HCII 2007, LNCS 4554, pp.933-941.

Kobayashi, M., Hiyama, A. AND MiURA, T., 2011. Elderly user evaluation of mobile touchscreen interactions. In P. Campos et al., ed. INTERACT 2011, Part I, LNCS 6946. pp. 83-99.

KuRNIAWAN, S. AND ZAPHIRIS, P., 2005. Research-derived web design guidelines for older people. In Proceedings of the 7th international ACM SIGACCESS conference on Computers and accessibility - Assets '05. New York, New York, USA: ACM Press, p. 129.

Lee, J., Poliakoff, E. And Spence, C., 2009. The effect of multimodal feedback presented via a touch screen on the performance of older adults. M.E. Altinsoy, $U$. Jekosch, and S. Brewster (Eds.): HAID 2009, LNCS 5763, pp.128-135.

LEITAO, R. AND Silva, P., 2013. A study of novice older adults and gestural interaction on smartphones. MOBACC ACM CHI'13.

LEONARD, V.K., JACKO, J. A. AND PIZZIMENTI, J.J., 2005. An exploratory investigation 
of handheld computer interaction for older adults with visual impairments. Proceedings of the 7th international ACM SIGACCESS conference on Computers and accessibility - ASSETS'05, pp.12-19.

Leonardi, C., Albertini, A., Pianesi, F. And Zancanaro, M., 2010. An exploratory study of a touch-based gestural interface for elderly. In Proceedings of the 6th Nordic Conference on Human-Computer Interaction Extending Boundaries NordiCHI '10. New York, New York, USA: ACM Press, p. 845.

LEPICARD, G. AND VigOuROuX, N., 2012. Comparison between single-touch and multitouch interaction for older people. In Lecture Notes in Computer Science (including subseries Lecture Notes in Artificial Intelligence and Lecture Notes in Bioinformatics). pp. 658-665.

LEPICARD, G. AND VIGOUROUX, N., 2010a. Influence of age and interaction complexity on touch screen Color and position effects on user performance. 12th IEEE International Conference on e-Health Networking Applications and Services (Healthcom), pp.246 - 253.

LePICARD, G. AND VigOuROuX, N., 2010b. Touch Screen User Interfaces for Older Subjects Effect of the Targets Number and the Two Hands Use. K. Miesenberger et al. (Eds.): ICCHP 2010, Part II, LNCS 6180, pp.592-599.

LOUREIRO, B. AND Rodrigues, R., 2014. Design Guidelines and Design Recommendations of Multi-Touch Interfaces for Elders. In ACHI 2014: The Seventh International Conference on Advances in Computer-Human Interactions. pp. 41-47.

MerTEnS, A. AND Jochems, N., 2010. Design pattern TRABING: touchscreen-based input technique for people affected by intention tremor. Proceedings of the 2 nd ..., pp.267-272.

Moffatt, K. And McGrenere, J., 2007. Slipping and drifting: using older users to uncover pen-based target acquisition difficulties. In Proceedings of the 9th international ACM SIGACCESS conference on Computers and accessibility ASSETS'07. October 15-17, 2007, Tempe, Arizona, pp. 11-18.

Motti, L.G., VigourouX, N. AND GorCE, P., 2014. Design of a social game for older users using touchscreen devices and observations from an exploratory study. In C. Stephanidis and M. Antona, ed. UAHCI, HCII 2014, Part III 8. Springer-Verlag Berlin Heidelberg, pp. 69-78.

NiCOLAU, H. AND JORGE, J., 2012. Elderly text-entry performance on touchscreens. Proceedings of the 14th international ACM SIGACCESS conference on Computers and accessibility - ASSETS '12, p.127. 
NigAY, L. AND COUTAZ, J., 1996. Espaces conceptuels pour multimédia et multimodale 1' interaction. Techniques et sciences informatiques, spécial Multimédia et Collecticiel, AFCET \& Hermes Publ. 15(9)., pp.1195-1225.

Nischelwitzer, A. AND PintofFl, K., 2007. Design and development of a mobile medical application for the management of chronic diseases: methods of improved data input for older people. A. Holzinger (Ed.): USAB 2007, LNCS 4799, pp.119132.

Pedersen, E.W. AND HornBæK, K., 2012. An experimental comparison of touch interaction on vertical and horizontal surfaces. Proceedings of the 7th Nordic Conference on Human-Computer Interaction Making Sense Through Design NordiCHI'12, p.370.

PIPER, A.M., CAMPBell, R. AND Hollan, J.D., 2010. Exploring the accessibility and appeal of surface computing for older adult health care support. Proceedings of the 28th international conference on Human factors in computing systems - ACM CHI'10, pp.907-916.

PIPER, A.M. AND Hollan, J.D., 2013. Supporting medical communication for older patients with a shared touch-screen computer. International journal of medical informatics, 82(11), pp.e242-50.

RAU, P. AND HSU, J.H., 2005. Interaction devices and web design for novice older users. Educational Gerontology, 31, pp.19-40.

Rogers, W. A, Fisk, A.D., Mclaughlin, A.C. AND PAK, R., 2005. Touch a screen or turn a knob: choosing the best device for the job. Human factors and Ergonomics Society, 47(2), pp.271-88.

Rogers, Y., PaAy, J., Brereton, M., Vaisutis, K., Marsden, G. And Vetere, F., 2014. Never Too Old : Engaging Retired People Inventing the Future with MaKey MaKey. , pp.3913-3922.

SChNEIDER, N., WiLKes, Ja., GRANDT, M. AND SCHLICK, C., 2008. Investigation of Input Devices for the Age-differentiated Design of Human-Computer Interaction. In Human facttors and Ergonomics Society 52nd annual meeting. pp. 144-148.

SEARS, A. AND HANSON, V.L., 2011. Representing users in accessibility research. In Proceedings of ACM CHI'11. Vancouver, BC, Canada: ACM Press, pp. 22352238.

Smith, M., Sharit, J. AND CZAJA, S., 1999. Aging, motor control, and the performance of computer mouse tasks. Human Factors, 41(3), pp.389-396.

STÖßEL, C., 2009. Familiarity as a factor in designing finger gestures for elderly users. 
Proceedings of the 11th International Conference on Human-Computer Interaction with Mobile Devices and Services - MobileHCI '09, p.1.

STÖßEL, C., WANDKE, H. AND BLESSING, L., 2010. Gestural interfaces for elderly users: help or hindrance? In S. Kopp and I. Wachsmuth, ed. 8th International Gesture Workshop, GW 2009, LNAI 5934. Bielefeld, Germany, pp. 269-280.

TAVeiRA, A.D. AND CHOI, S.D., 2009. Review Study of Computer Input Devices and Older Users. International Journal of Human-Computer Interaction, 25(5), pp.455-474.

TSAI, W. AND LEE, C., 2009. A study on the icon feedback types of small touch screen for the elderly. Universal Access in Human-Computer Interaction., pp.422-431.

UMEMURO, H., 2004. Lowering elderly Japanese users? resistance towards computers by using touchscreen technology. Universal Access in the Information Society, 3(34), pp.276-288.

Vella, F., VigourouX, N. And Rumeau, P., 2011. Investigating drag and drop techniques for older people with cognitive impairment. In J. A. Jacko, ed. Human Computer Interaction, Part IV, HCII 2011, LNCS 6764. Springer-Verlag Berlin Heidelberg, pp. 530-538.

Vetter, S., BÜtzler, J., Jochems, N. AND Schlick, C., 2011. Fitts' Law in Bivariate Pointing on Large Touch Screens: Age-Differentiated Analysis of Motion Angle Effects on Movement Times and Error Rates. C. Stephanidis (Ed.): Universal Access in HCI, Part II, HCII 2011, LNCS 6766, pp.620-628.

Vigouroux, N., Rumeau, P., Vella, F. And Vellas, B., 2009. Studying Point-SelectDrag Interaction Techniques for Older People with Cognitive Impairment. In C. Stephanidis, ed. UAHCI, Part I, HCII 2009, LNCS 5614. pp. 422-428.

WACHARAMANOTHAM, C., 2011. Evaluating swabbing: a touchscreen input method for elderly users with tremor. Proceedings of ACM CHI'11, pp.623-626.

WAGNER, J., HuOT, S. AND MACKAY, W., 2012. Bitouch and bipad: Designing bimanual interaction for hand-held tablets. CHI'12 (ACM), 2012(May).

WöcKL, B., Yildizoglu, U. AND BUBER, I., 2012. Basic senior personas: a representative design tool covering the spectrum of European older adults. ASSETS'12, In Proceedings of the 14th international ACM SIGACCESS conference on Computers and accessibility (ASSETS '12). ACM, New York, NY, USA, October 22-24, Boulder, Colorado, USA., pp.25-32.

Wood, E., Willoughby, T., Rushing, A., Bechtel, L. AND Gilbert, J., 2005. Use of computer input devices by older adults. Journal of Applied Gerontology, 24(5), 
pp.419-438.

Wright, P., Bartram, C., Rogers, N. And Emslie, H., 2000. Text entry on handheld computers by older users. Ergonomics, 43:6(May 2013), pp.37-41.

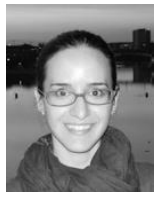

Lilian Genaro Motti est étudiante en doctorat à l'Institut de Recherche en Informatique de Toulouse. Le sujet de sa thèse porte sur les interactions des personnes âgées avec les écrans tactiles. Précédemment, elle a travaillé quatre ans en tant qu'animatrice multimédia à l'espace multimédia de la Ville de Meudon, où elle a initié des personnes âgées à l'usage de l'ordinateur et d'internet. Le cœur de ses travaux porte sur le développement de systèmes interactifs afin de mieux comprendre et répondre aux besoins des utilisateurs âgés.

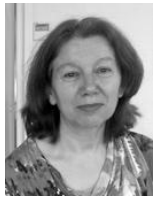

Nadine Vigouroux est chargée de recherche à l'Institut de Recherche en Informatique de Toulouse. La thématique principale de ses activités relève de l'interaction homme-machine et plus particulièrement les méthodes, les modèles et les outils pour l'étude de communication/interaction dégradée que celle-ci soit induite par l'usager et/ou environnement - en vue de la spécification d'outils de suppléance ou des stratégies palliatives au service des personnes handicapées et âgées.

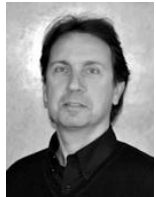

Philippe Gorce est le directeur du laboratoire HandiBio à l'Université du Sud Toulon Var, spécialisé dans la bio-modélisation et l'ingénierie du handicap. Il travaille actuellement sur la compensation des mouvements altérés, plus spécialement sur le handicap moteur. 